\title{
Study of the Adsorption Efficiency of an Eco-Friendly Carbohydrate Polymer for Contaminated Aqueous Solution by Organophosphorus Pesticide
}

\author{
Z. Abdeen ${ }^{1 *}$, Somaia G. Mohammad ${ }^{2}$ \\ ${ }^{1}$ Petrochemical Department, Egyptian Petroleum Research Institute, Nasr City, Cairo, Egypt \\ ${ }^{2}$ Pesticide Residues and Environmental Pollution Department, \\ Central Agricultural Pesticides Laboratory, Agriculture Research Center, Dokki, Giza, Egypt \\ Email: 'ziziabdeen@yahoo.com
}

Received October 19, 2013; revised November 19, 2013; accepted November 26, 2013

Copyright (C 2014 Z. Abdeen, Somaia G. Mohammad. This is an open access article distributed under the Creative Commons Attribution License, which permits unrestricted use, distribution, and reproduction in any medium, provided the original work is properly cited. In accordance of the Creative Commons Attribution License all Copyrights (C) 2014 are reserved for SCIRP and the owner of the intellectual property Z. Abdeen, Somaia G. Mohammad. All Copyright @ 2014 are guarded by law and by SCIRP as a guardian.

\begin{abstract}
The removal of pesticide (ethoprophos) from aqueous solution using a natural biosorbent such as chitosan (CH) prepared from a biopolymer waste obtained from marine industry was studied. The Fourier Transform Infrared Spectroscopy (FTIR), Scanning electron microscopy (SEM), and X-ray diffraction spectroscopy (XRD) were used to study the structure of the adsorbent. The biosorption studies were carried out under various parameters, such as biosorbent dose, initial pesticide concentration and contact time. The experimental results show that the removal percentage of ethoprophos increased from $85.693 \%$ to $89.234 \%$, as adsorbent dose $(\mathrm{CH})$ increased from 0.02 to $0.1 \mathrm{~g} / 100 \mathrm{ml}$. The equilibrium uptake was increased with an increase in the initial pesticide concentration in solution. Biosorption kinetic data were fitted well with the pseudo-second order kinetic model. The experimental isotherms data were analyzed using Freundlich, Langmuir, Temkin and Dubinin-Radushkevich (D-R) isotherm equations. The best fit was obtained by Freundlich isotherm with high correlation coefficients. That the value of energy calculated from the $D-R$ isotherm was $5.56 \mathrm{KJ} / \mathrm{mol}$ suggests the adsorption of ethoprophos on Chitosan is physical. All the results indicating $\mathrm{CH}$ was chosen as low-cost biosorbent could be applied for the removal of organophosphorous pesticide from aqueous solutions.
\end{abstract}

\section{KEYWORDS}

Chitosan; Adsorption; Organophosphorous; Pesticide; Contaminated

\section{Introduction}

The contamination of surface and ground water by pesticides has become a serious environmental problem in recent years due to the extensive application of these agrochemicals in crop farms, orchards, fields and forest lands. This contamination arises from surface runoff, leaching, wind erosion, deposition from aerial applications, industrial discharges and various other sources. Consequently, pesticides have frequently been detected in water bodies in different countries of the world [1-3]. Pesticides are harmful to life because of their toxicity, carcinogenicity and mutagenicity [4]. The harmful influence of pesticides

*Corresponding author. on human health and the environment has resulted in the imposition of stringent legislation on drinking water quality in many countries [5]. Ethoprophos (O-ethyl S,S-dipropyl phosphorodithioate) is organophosphorus nematicide and insecticide usually applied for the control of plant parasitic nematodes and soil insects in potatoes, sweet potatoes, tomatoes, vegetables, maize, soybeans, peanuts, bananas, citrus and other crops. The half-life $\left(t^{1 / 2}\right)$ of ethoprophos varies from 3 to 30 days. The contamination of surface and ground water by pesticides has become a serious environmental problem in recent years. The toxicity of pesticides and their degradation products are making these chemical substances a potential hazard by contaminating our environment [6]. Therefore, the removal of 
pesticides from water is one of the major environmental concerns these days. There are several procedures available for removal of pesticides from water which includes photocatalytic degradation $[7,8]$, ultrasound combined with photo-Fenton treatment [9], advanced oxidation processes [10], aerobic degradation [11], electrodialysis membranes [12], ozonation [13] and adsorption [14]. The adsorption process is one of the most efficient methods of removing pollutants from wastewater. Also, the adsorption process provides an attractive alternative treatment, especially if the adsorbent is inexpensive and readily available [15]. Many studies have been made on the possibility of adsorbents using activated carbon [16-18], peat [19], chitin [20], silica [21], fly ash [22], clay [23] and others [24, 25]. A very promising natural material that can be obtained in large quantities and cheap is chitosan, a nitrogenous polysaccharide. Chitosan and its derivatives are examples of value-added materials. They are produced from chitin, which is a natural carbohydrate polymer found in the skeleton of crustaceans, such as crab, shrimp and lobster, as well as in the exoskeleton of marine zooplankton spp., including coral and jellyfishes [26]. Insects, such as butterflies and ladybugs, also have chitin in their wings and the cell walls of yeast, mushrooms and other fungi also contain this substance [27]. Chitosan is the deacetylated form of chitin, which is a linear polymer of acetylamino D-glucose. It is structurally similar to cellulose, but it is an amino polymer and has acetamide groups at the C-2 positions in place of the hydroxyl groups. Recently, chitosan which is used as an adsorbent has drawn attentions due to its high contents of amino and hydroxyl functional groups showing high potentials of the adsorption of dyes [28], metal ions [29], and proteins [30]. Other useful features of chitosan include its abundance, hydrophilicity, biocompatibility, biodegradability and antibacterial property [31]. Chitosan has good adsorption capability, due to the low porosity and weak mechanical property. Chitosan and its derivatives exhibit innumerable applications in a wide range of fields such as food preservation [32,33], pharmacy [34-36], biomedicine [37-39], cosmetics [40], biotechnology [41], dietary supplements, water treatment and agriculture [42]. These versatile materials are also widely applied in the textile, pulp and paper industries. However, only a limited number of published studies can be found in the use of chitosan as an adsorbent for pesticides removal. The use of chitosan as a precursor will provide a solution to environmental problems caused by this waste as well as produce a value-added product from a low-cost material. Therefore, in this study, removal of ethoprophos from aqueous solutions by chitosan $(\mathrm{CH})$ was studied. Experimental parameters affecting the adsorption process such as adsorbent dose, initial ethoprophos concentration and contact time for removal were optimized. The equilibrium and kinetic data of the adsorption were studied to describe the adsorption process.

\section{Materials and Methods}

\subsection{Materials}

Hydrochloric acid, oxalic acid, potassium permanganates, sodium chloride, potassium hydroxide, sodium hydroxide and O-ethyl S,S-dipropyl phosphorodithioate were purchased from Merck, Germany, and were used without further purification.

\subsubsection{Adsorbate}

The pesticide used as adsorbate in the experiments is ethoprophos. Some properties and chemical structure of the pesticide is given in Table 1 .

\subsubsection{Adsorbent $(\mathrm{CH})$}

The shrimp shells were collected from sea food shops and washed under running water to remove soluble organics, adherent proteins and other impurities. Then it dried in oven at $70^{\circ} \mathrm{C}$ for $24 \mathrm{~h}$ or longer until completely dried shells were obtained.

\subsection{Preparation of Chitosan}

The chitinous material (shells of the shrimp) was decalcificated with $1.0 \mathrm{M} \mathrm{HCl}(3.0 \% \mathrm{w} / \mathrm{v})$ at room temperature with constant stirring for 1.5 hours. The decalcified product was filterated, washed and dried, then deproteinized with $4 \% \mathrm{NaOH}$ solution at $50^{\circ} \mathrm{C}$ with constant stirring for 5 hours. The deproteinized chitin was filtered and washed with de-ionized distilled water until the $\mathrm{pH}$ became neutral. It was dehydrated twice with methanol, and once with acetone, and dried. The dried chitin was added to boiling $0.1 \%$ potassium permanganate solution to remove the odor and to $15 \%$ oxalic acid solution to remove the color. The product chitin was filtered, washed

Table 1. Some properties and chemical structure of ethoprophos.

\begin{tabular}{cc}
\hline Common name & Ethopropho \\
\hline Chemical structure & O-ethyl S,S-dipropyl phosphorodithioate \\
Name & Organophosphorus \\
Pesticide group & Non-systemic nematicide and insecticide \\
Activity & $\mathrm{C}_{8} \mathrm{H}_{19} \mathrm{O}_{2} \mathrm{PS}_{2}$ \\
Molecular formula & 242.3 \\
MW & $700 \mathrm{mg} / \mathrm{L}$ \\
$\mathrm{S}^{\mathrm{b}}$ (g/L) & $10 \% \mathrm{GR}$ \\
Formulation & $30 \mathrm{Kg} / \mathrm{Feddan}$ \\
Rate of application & $\mathrm{CCH}_{2} \mathrm{CH}_{3}$ \\
\hline
\end{tabular}

Data were obtained from [43]. ${ }^{\mathrm{a}}$ Molecular weight. ${ }^{\mathrm{b}}$ Solubility in water at $25^{\circ} \mathrm{C}$. 
with distilled water and dried. The chitosan was prepared by adding the dried chitin into a three-necked flask containing a solution of $40 \%(\mathrm{w} / \mathrm{v}) \mathrm{KOH}$, Scheme 1 . It was refluxed under nitrogen atmosphere at $135^{\circ} \mathrm{C}-140^{\circ} \mathrm{C}$ for 2 hours [44]. The deacetylated chitin (chitosan) was filtered, washed with distilled water, and dried. Then the adsorbent (Ch) were ground using ball mail (Reech, PM400, Germany).

\subsection{Adsorption Experiments}

The adsorption experiments of ethoprophos onto $\mathrm{CH}$ were carried out in a set of 150 Erlenmeyer flasks. $100 \mathrm{ml}$ of the pesticide solutions of various initial concentrations in the range 10 - $60 \mathrm{mg} / \mathrm{L}$ were added to separate flasks and a fixed dose of $0.1 \mathrm{~g}$ of $\mathrm{CH}$ was added to each flask covered with glass stopper at normal $\mathrm{pH} 5.48$, room temperature $\left(25^{\circ} \mathrm{C} \pm 2^{\circ} \mathrm{C}\right)$, for contact time $24 \mathrm{~h}$, with occasional agitation to reach equilibrium. The $\mathrm{CH}$ dose used is the optimum in the range of initial concentrations of pesticide studied and was obtained from preliminary studies. For kinetic studies of ethoprophos onto $\mathrm{CH}, 100 \mathrm{ml}$ of the solution containing $10-60 \mathrm{mg} / \mathrm{L}$ with $0.1 \mathrm{~g}$ of $\mathrm{CH}$ for different time intervals from 5 to 300 minutes to determine the equilibrium time. From the triplicate flasks, 40 $\mathrm{ml}$ of filtrate was transferred to a separatory funnel and extracted successively three times with 20, 15 and $10 \mathrm{ml}$ portions of dichloromethane. The combined extract was dried on anhydrous sodium sulfate to remove moisture content and evaporated using a rotary evaporator on a water bath at $40^{\circ} \mathrm{C}$. The extracted samples were analyzed using GC-FPD. Isothermal studies of ethoprophos were conducted with an adsorbent quantity of $0.1 \mathrm{~g}$ of $\mathrm{CH}$ with pesticide concentrations of 10 - $60 \mathrm{mg} / \mathrm{L}$ in identical conical flasks containing $100 \mathrm{ml}$ of distilled water. Blank solutions were treated similarly (without adsorbent).

\subsection{Characterization of the Prepared Chitosan (CH)}

\subsubsection{Degree of Deactylation}

Infrared spectra were measured by a Ati Mattson FTIR spectrophotometer. The deacetylated chitin (chitosan) $\mathrm{CH}$ was subjected to infrared spectroscopy to calculate the degree of deactylation (D.D) \%, by the relationship:

$$
\text { D.D }=100-[(\text { A1660/A3450 }) \times 100 / 1.33](\%),
$$

Where, $\mathrm{A}=$ absolute height of the absorption band of the amide group and hydroxyl group respectively [45].

\subsubsection{Degree of Swelling}

Swelling is the most significant characteristic of hydrogels and it reflects the affinity of the chemical structure of hydrogels for water and other surrounding fluids.

\section{Preparation of Chitosan Gel Film.}

Gel was prepared by dissolving $2 \%$ (w/v) chitosan in $1 \%(\mathrm{v} / \mathrm{v})$ aqueous acetic acid with constant stirring at room temperature. The vicious solution prepared was filtered through a cheese cloth to remove any impurities and cast in petri dish to dry forming thin film. A known weight of the $\mathrm{CH}$ film was immersed in solutions of different $\mathrm{pH}(5,7)$ at $40^{\circ} \mathrm{C}$ and $25^{\circ} \mathrm{C}$ until the swelling equilibrium was reached. The film was removed, dried with absorbent paper to get rid of excess water then weighed. The degree of swelling of these samples was calculated with the following equation:

$$
D S=\left(m-m^{\prime}\right) / m^{\prime}
$$

Where $m$ and $m^{\prime}$ denote the weights of sample and dried sample, respectively [46].

\subsubsection{Molecular Weight Determination}

Molecular weight is also one of the significant characteristics that control the functional properties of $\mathrm{CH}$. Viscosity is one of the simple techniques that is widely used for estimation of the molecular weights of polymers. The viscosity-average molecular weight was calculated using Mark-Houwink equation relating to intrinsic viscosity [47].

$$
[\eta]=K_{m} M v^{a}
$$

Where $K_{m}=8.93 \times 10^{-4}$ and a $=0.716$ at $25^{\circ} \mathrm{C}$ are the empirical viscometer constants that are specific for a given polymer, solvent and temperature.

\subsubsection{Thermogravimetric Analysis (TGA)}

The thermal stability of the chitosan was studied using a thermogravimetric analyzer (TGA). All TGA spectra were recorded under a nitrogen atmosphere up to $600^{\circ} \mathrm{C}$ using a programmed rate of $10^{\circ} \mathrm{C} / \mathrm{min}$.

\subsubsection{X-Ray Diffraction Measurements}

XRD patterns were obtained on Siemens (Berlin, Germany) D500 diffractometer with a back monochromator and a $\mathrm{Cu}$ anticathode.

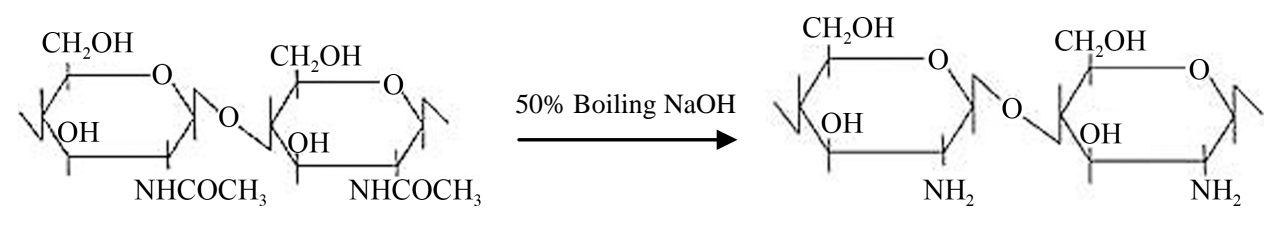

Scheme 1 . The preparation of chitosan by deactylation of chitin. 
2.4.6. Scanning Electron Microscopy Testing Phase morphology was studied using a JSM-T20 (JEOL, Tokyo, Japan) scanning electron microscope (SEM). For scanning electron observations, the surface of the sample was mounted on a standard specimen stub. A thin coating $\left(\sim 10^{-6} \mathrm{~m}\right)$ of gold was deposited into the sample surface and attached to the stub prior to SEM examination in the microscope to avoid electrostatic charging during examination.

\subsection{Determination of Adsorption Capacity}

The adsorption capacity was determined by using the following equation, taking into account the concentration difference of the solution at the beginning and at equilibrium [48].

$$
q_{e}=\frac{\left(C_{0}-C_{e}\right) V}{m}
$$

Where $C_{0}$ and $C_{e}$ are the initial and the equilibrium ethoprophos concentration $\mathrm{mg} / \mathrm{L}$, respectively, $V$ is the volume of solution (ml) and $\mathrm{m}$ is the amount of adsorbent used (g). The removal percentage can be calculated as:

$$
\text { Removal percentage }=\frac{C_{0}-C_{e}}{C_{0}} \times 100
$$

\subsection{Determination of Ethoprophos Concentration}

The concentration of ethoprophos was determined by HP 7890 A series Gas Chromatograph (GLC), equipped with Flame Photometric Detector (FPD) operated in the phos- phorus mode (525 nm filter) under the following conditions. The used column was PAS: 1701 (30.00 $\mathrm{m} \times 0.32$ $\mathrm{mm}$ and $0.25 \mathrm{~m} \mu$ film thickness. Detector temperature was $250^{\circ} \mathrm{C}$, injector temperature was $245^{\circ} \mathrm{C}$, and the column temperature was programmed so that reaches to $190^{\circ} \mathrm{C}$ and hold on 2 minutes, then rose to $240^{\circ} \mathrm{C}$, at a rate of $10^{\circ} \mathrm{C} \mathrm{min}{ }^{-1}$ and hold on 5 minutes. Nitrogen carrier gas flow rate was $4 \mathrm{ml} \cdot \mathrm{min}^{-1}$, hydrogen flow was 75 $\mathrm{ml} \cdot \mathrm{min}^{-1}$ and air flow was $100 \mathrm{ml} \cdot \mathrm{min}^{-1}$.

\section{Results and Discussion}

From FTIR analysis was shown in Figure 1, the degree of deactylation (D.D) of the prepared chitosan $\mathrm{CH}$ was calculated and found to be $61.67 \%$. The FTIR spectra of chitosan and with its adsorbent are shown in Figure 1, for comparison. The band at $3500-3300 \mathrm{~cm}^{-1}$ contributing to the $\mathrm{NH}_{2}$ Stretching of the primary amine, the band at $3500-3200 \mathrm{~cm}^{-1}$ corresponds to $\mathrm{OH}$ bonded groups and $-\mathrm{NH}_{3}^{+}$, it makes a broad peak in the spectrum. The spectra also shows the peaks around $1420 \& 1450 \mathrm{~cm}^{-1}$ contributing to $-\mathrm{CH}_{2} \mathrm{COOH}$ group, moderate peaks at 1651 \& $1597 \mathrm{~cm}^{-1}$ referred to $\mathrm{C}=\mathrm{O}$ group of acetyl groups, which are more appear in the $\mathrm{CH}$-absorbent than that in the $\mathrm{CH}$ sample. The spectra also shows the peaks around $1427 \& 1450 \mathrm{~cm}^{-1}$ contributing to $-\mathrm{CH}_{2} \mathrm{COOH}$ group, moderate peaks at $1652 \& 1597 \mathrm{~cm}^{-1}$ referred to $\mathrm{C}=\mathrm{O}$ group of acetyl groups. The $\mathrm{NH}_{2}$ stretch of amide groups \& $\mathrm{CH}_{2}$ stretch, C- $\mathrm{CH}_{2}$, C-O and $\mathrm{NH}$ out-of-plane, all these peaks are appeared at 2920, 1427, 1090, 640 $\mathrm{cm}^{-1}$ respectively. The identically in the peaks confirmed that there is a small difference between the groups of chitosan and Ethoprophos. FTIR spectrum of chitosan

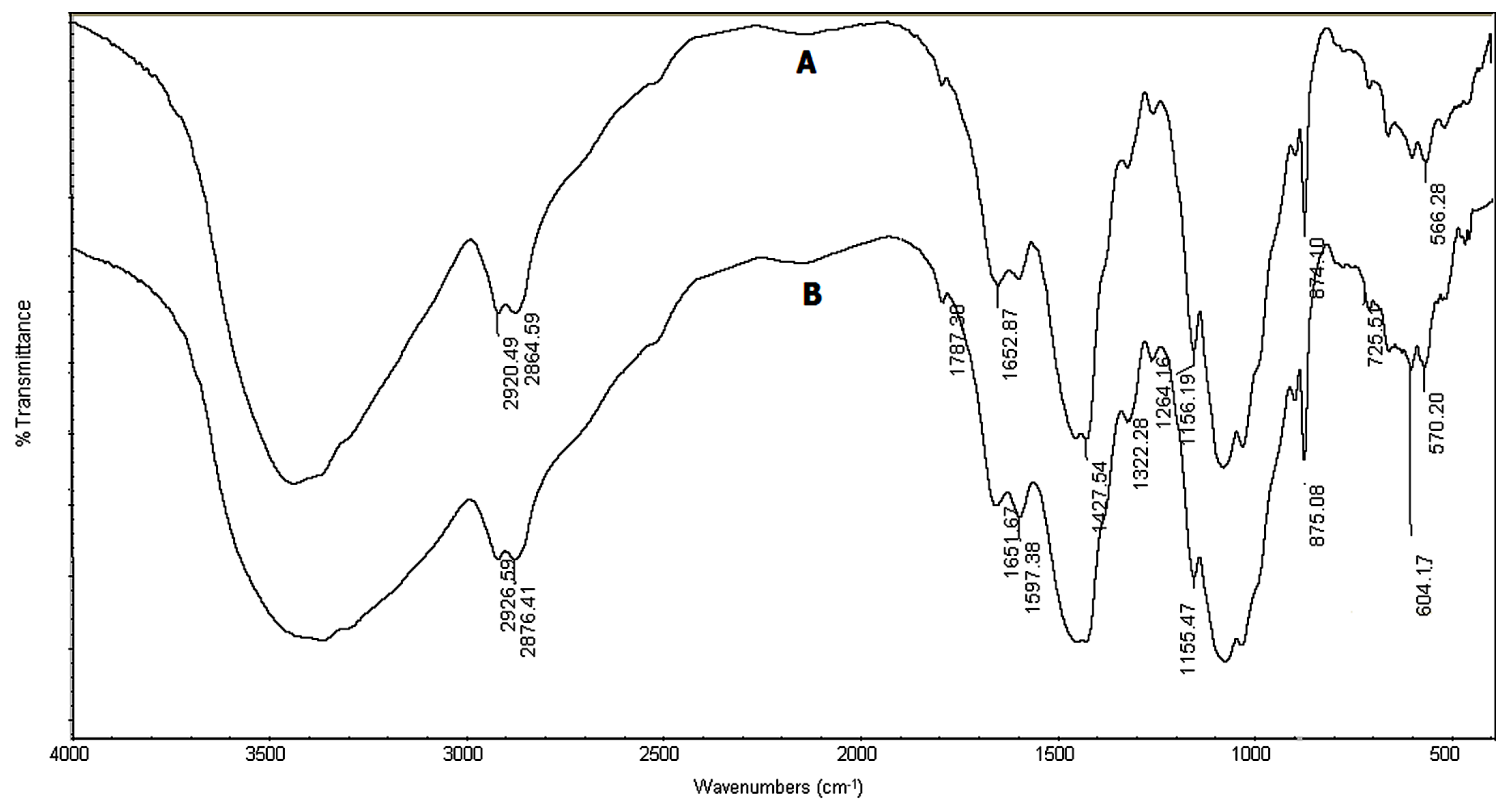

Figure 1. IR spectra of chitosan before (A)and after adsorption(B). 
powder shows characteristic hydroxyl group and stretching vibrations of C-O group at $1787 \mathrm{~cm}^{-1}$. The bending vibrations of $\mathrm{C}-\mathrm{H}$ bond in $-\mathrm{CH}_{2}$ are located at $2926 \mathrm{~cm}^{-1}$ and in $-\mathrm{CH}_{3}$ group are located at $2876 \mathrm{~cm}^{-1}$. The band at $1651 \mathrm{~cm}^{-1}$ is related to the stretching vibrations of amide group carbonyl bonds C-O and the band at $1597 \mathrm{~cm}^{-1}$ is related to the stretching vibrations of amine group. Bending vibrations of methylene and methyl groups are located at $1322 \mathrm{~cm}^{-1}$ and $1450 \mathrm{~cm}^{-1}$, respectively. The spectrum in the range from 1150 to $1000 \mathrm{~cm}^{-1}$ is attributed to stretching vibrations of $\mathrm{C}-\mathrm{O}$ groups. The characteristic bands needed to confirm complexation between chitosan and Ethoprophos are shifted to the higher frequency.

Characteristic amide group from chitosan located at $1651 \mathrm{~cm}^{-1}$ is shifted to higher frequencies, to $1720 \mathrm{~cm}^{-1}$. The peak located at $1540 \mathrm{~cm}^{-1}$, which corresponds to the $\mathrm{NH}_{2}$-group form chitosan, is shifted to higher frequency,1590 $\mathrm{cm}^{-1}$, indicating that the acetic acid residue $\left(\mathrm{CH}_{3} \mathrm{COO}-\right)$ is attached to amine group in the chitosan chain. The shift of amide and amine group can be related to the electrostatic interaction between these groups and the negatively charged sites in the Ethoprophos structure, which confirm complexation between chitosan and Ethoprophos. The changes in the FTIR spectrum of the powders after binding with the Ethoprophos are significant. The -OH stretching, observed as strong broad band at $3445 \mathrm{~cm}^{-1}$ in unloaded $\mathrm{CH}$, shifts to $3430 \mathrm{~cm}^{-1}$ after binding Ethoprophos. These results confirm that $-\mathrm{CONH}_{2}$, $-\mathrm{NH}_{2}$ and $-\mathrm{OH}$ groups from chitosan, are involved in binding of Ethoprophos.

\subsection{Degree of Swelling}

It is evident from the results of the swelling properties represented in Figure 2 that, they are affected by the, $\mathrm{pH}$ and temperature. The chitosan polymer contains more amino groups, $-\mathrm{NH}_{2}$, which posses a high degree of deactylation, easily protonated to form more $-\mathrm{NH}_{3}^{+}$groups in acidic solution (acetic acid). The high swelling properties is due to the strong electrostatic interaction between the $\mathrm{NH}_{3}^{+}$groups of chitosan and hydroxyl group of water.

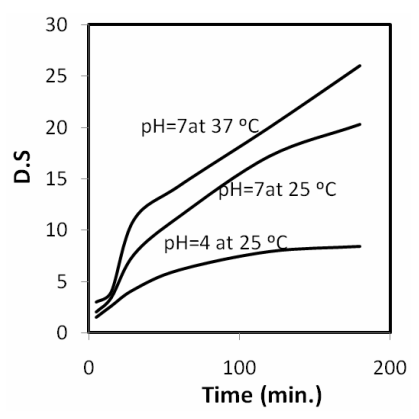

Figure 2. The degree of swelling (D.S) of $\mathrm{CH}$ samples, (at different PH \& temperatures), at time intervals.
These properties decreased at $\mathrm{pH}=5$, but increased at $\mathrm{pH}$ $=5$ at $40^{\circ} \mathrm{C}, \mathrm{pH}=7$ at $25^{\circ} \mathrm{C}$ and $\mathrm{pH}=7$ at $40^{\circ} \mathrm{C}$. These results are attributed to the increase in the mobility of the molecules with increase of temperature; this leads to increase in the porosity of the surface of the chitosan molecules and increase in its swelling properties. At $\mathrm{Ph}<7$, the decrease in the ratio of -OH groups leads to decrease in the swelling properties. The chitosan polymer which contains more amide groups cannot be easily protonated in acidic solutions. Since the electron withdrawal by carbonyl groups makes the nitrogen of the amide groups a much poorer source of electrons than that of the amino groups, and so the electrons are less available for sharing with hydrogen ions.

\subsection{Molecular Weight Determination of $\mathrm{CH}$}

The viscosity-average molecular weight $\left(M_{v}\right)$ of the prepared chitosan sample $\mathrm{CH}$ was determined by using an Ostwald viscometer at $25^{\circ} \mathrm{C}$ in $0.3 \mathrm{M}$ acetic acid and 0.2 $\mathrm{M}$ sodium acetate buffer solution and were calculated by using equation [3]. AS shown in Figure 3, the intrinsic viscosity $[\eta]$ of the prepared chitosan $\mathrm{CH}$ sample, are = $3.5 \mathrm{dl} / \mathrm{g}$ and the viscosity-average molecular weight $\left(M_{v}\right)$ was 99,998 Da.

\subsection{Thermal Properties Thermogravimetric Analysis (TGA)}

The previous investigations have shown that the decomposition of chitosan has 2 endothermic processes, the first one around $60^{\circ} \mathrm{C}$ for water evaporation, and the second one starts around $225^{\circ} \mathrm{C}$ and reaches a maximum $260^{\circ} \mathrm{C}$. Thermal degradation of pure chitosan, as Shown in Figure 4 , can have charred residue of up to $39 \%$ at $450^{\circ} \mathrm{C}$.

\subsection{Scanning Electron Microscopy (SEM)}

SEM is a widely used technique to study morphology

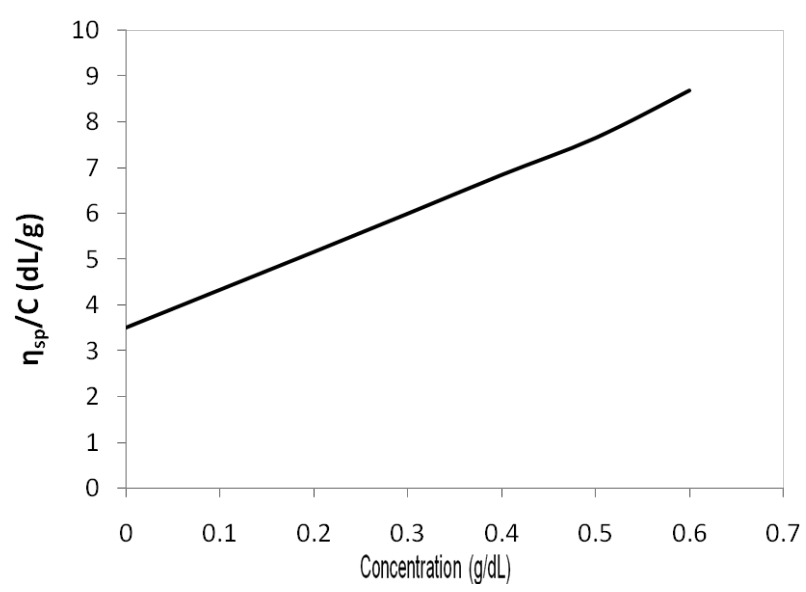

Figure 3. The reduced viscosity of chitosan vs. concentration at $25^{\circ} \mathrm{C}$. 


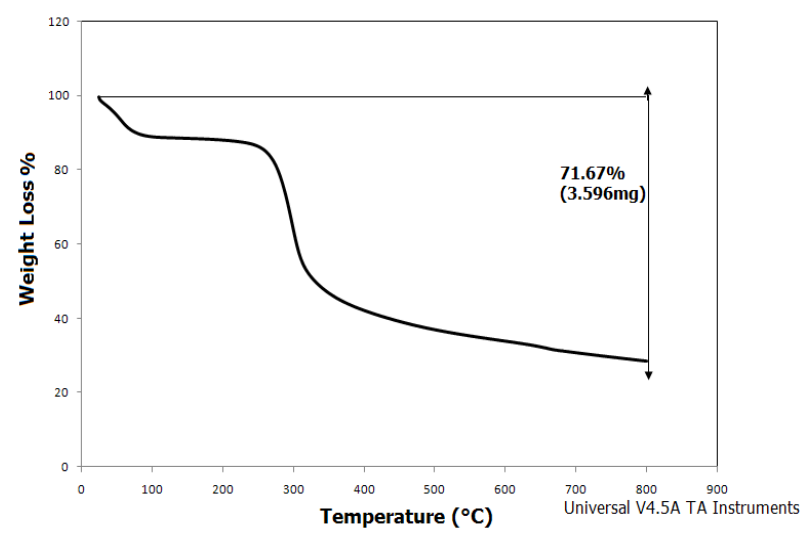

Figure 4. TGA of chitosan.

and surface characteristics of the adsorbent. Figure 5 presents the SEM micrographs illustrating the morphology of the adsorbent (chitosan) before (A) and after (B) adsorption. The micrographs after adsorption of ethoprophos had their surfaces covered with irregular adhered substances which were suspected to be the adsorbate molecules; unlike the structure of the adsorbent before adsorption which had a clear plain surface.

\subsection{X-Ray Diffraction (XRD)}

The XRD pattern of chitosan prepared from shrimp shells waste at Figure 6, exhibits the weak diffraction peaks centered at diffraction angle $2 \theta=11.9^{\circ}$ and sharp diffraction peaks at $2 \theta=20^{\circ}$ are indicative of the high degree of crystallinity morphology of chitosan.

\subsection{The Effect of Biosorbent Dose}

Adsorbent dose is an important parameter influencing adsorption processes since it determines the adsorption capacity of an adsorbent for a given initial concentration of the adsorbate at the operating conditions. The effect of $\mathrm{CH}$ dose on removal of ethoprophos was studied in range of $0.02-0.1 \mathrm{~g} / 100 \mathrm{ml}$. Figure 7 showed that the removal percentage of pesticide increased from $85.693 \%$ to $89.234 \%$, as adsorbent dose $(\mathrm{CH})$ increased from 0.02 to $0.1 \mathrm{~g} / 100 \mathrm{ml}$. Such a trend is attributed to an increase in the adsorptive surface area and the availability of more binding sites. Further increase in adsorbent dose, did not show significant increase in removal percentage of pesticide, therefore, $0.1 \mathrm{~g} / 100 \mathrm{ml}$ adsorbent dose was chosen for the successive experiments. Similar behaviour for the effect of biosorbent dosage on dye adsorption capacity was observed for different types of sorbents [49,50].

\subsection{The Effect of Initial Pesticide Concentration on Biosorption}

The effect of ethoprophos concentration by $\mathrm{CH}$ was studied at different initial pesticide concentrations of 10, 20,

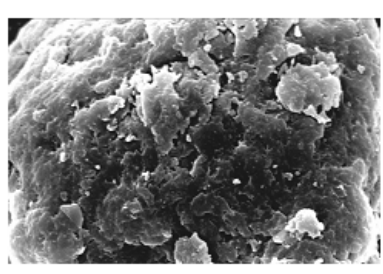

(a)

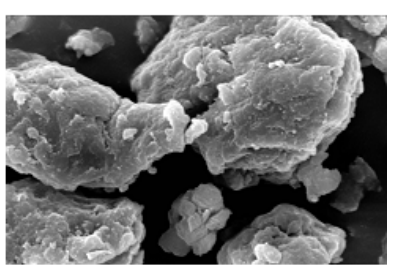

(b)
Figure 5. The SEM of chitosan bowder before (a) and after adsorption (b).

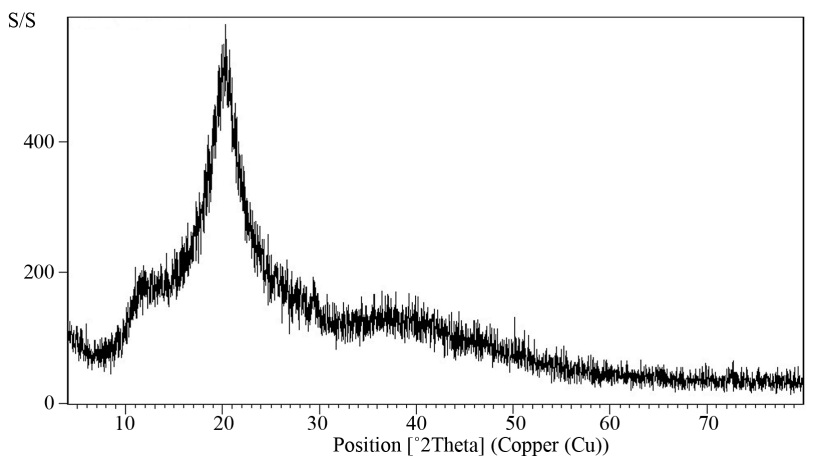

Figure 6. The XRD pattern of prepared chitosan.

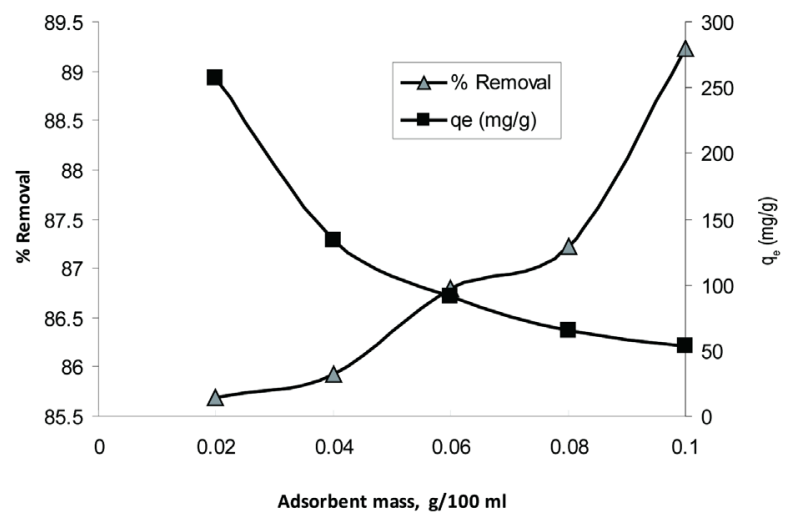

Figure 7. The effect of biosorbent dose on ethoprophos removal onto $\mathrm{CH}\left(C_{0}: 60 \mathrm{mg} / \mathrm{L}\right.$, temperature: $\left.25^{\circ} \mathrm{C} \pm 2^{\circ} \mathrm{C}\right)$.

30, 40, 50 and $60 \mathrm{mg} / \mathrm{L}$. Figure 8 shows that the adsorption capacity increased from 9.399 to $54.706 \mathrm{mg} / \mathrm{g}$ with increasing of the ethoprophos concentration. This is probably due to increase in the driving force of the concentration gradient, as an increase in the initial pesticide concentration [51]. However, the removal percentage of ethoprophos reduced from $93.994 \%$ to $87.76 \%$ with increasing concentration of the pesticide. At higher pesticide concentrations, lower pesticide removal percentage is probably due to the saturation of sorption sites. Similar results were reported by other workers for coniferous bark power [52] and tea [53].

\subsection{The Effect of Contact Time on Biosorption}

The effect of contact time was first investigated to deter- 


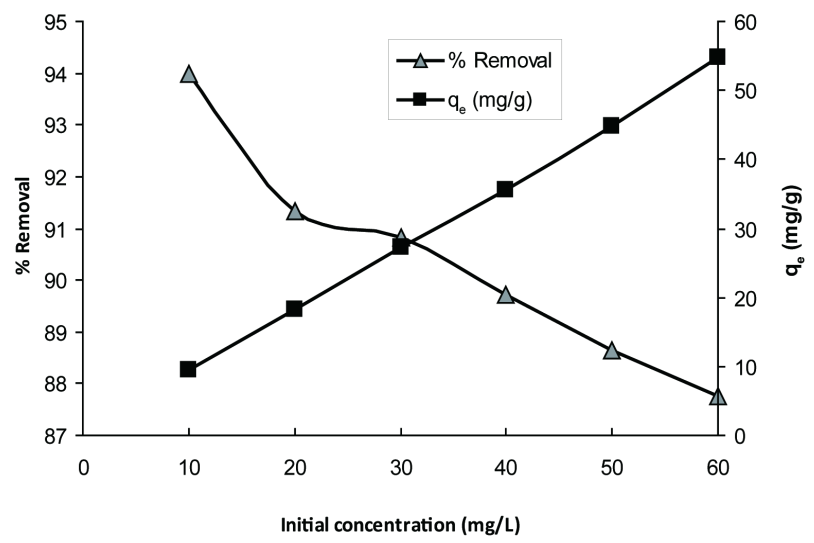

Figure 8. The effect of initial concentration for removal of ethoprophos by $\mathrm{CH}$ (biosorbent dose, $0.1 \mathrm{~g} / 100 \mathrm{ml}$, temperature: $25^{\circ} \mathrm{C} \pm 2^{\circ} \mathrm{C}$ ).

mine the equilibrium time for ethoprophos adsorption onto $\mathrm{CH}$ at $25^{\circ} \mathrm{C} \pm 2^{\circ} \mathrm{C}$. Figure 9 shows the effect of contact time on the adsorption of ethoprophos at different initial concentrations by chitosan. The pesticide adsorption rate was high in the first 30 min for all initial concentrations of pesticides investigated and finally attained after $180 \mathrm{~min}$. The rapid pesticide adsorption at the initial stages of contact time could be attributed to the large number of active sites available on the surface of chitosan. Afterwards with the gradual occupancy of these sites, the sorption became less efficient. This is in agreement with the results obtained for hazelnut shell [54].

\subsection{Equilibrium Isotherms}

The equilibrium adsorption isotherm has the importance in the design of adsorption systems [55]. The equilibrium data were analyzed by the most commonly used isotherms; Langmuir, Freundlich, Temkin isotherm and DubininRadushkevich (D-R) models [56-59].

\subsubsection{Langmuir Isotherm}

The Langmuir equation, which is valid for monolayer adsorption onto a completely homogeneous surface with a finite number of identical sites and with negligible interaction between adsorbed molecules, is represented in the linear form as follows [60].

$$
\frac{C_{e}}{q_{e}}=\frac{1}{Q_{m} b}+\frac{C_{e}}{Q_{m}}
$$

Where $q_{e}(\mathrm{mg} / \mathrm{g})$ and $C_{e}(\mathrm{mg} / \mathrm{L})$ are the amount of adsorbed ethoprophos per unit mass of adsorbent and ethoprophos concentration at equilibrium, respectively. $Q_{m}$ is the maximum amount of the ethoprophos per unit mass of adsorbent to form a complete monolayer on the surface bound at high $C_{e}$ and $b$ is the Langmuir constant $(\mathrm{L} / \mathrm{mg})$. The plot of specific adsorption $\left(C_{e} / q_{e}\right)$ against the equilibrium concentration $\left(C_{e}\right)$ Figure 10, shows that

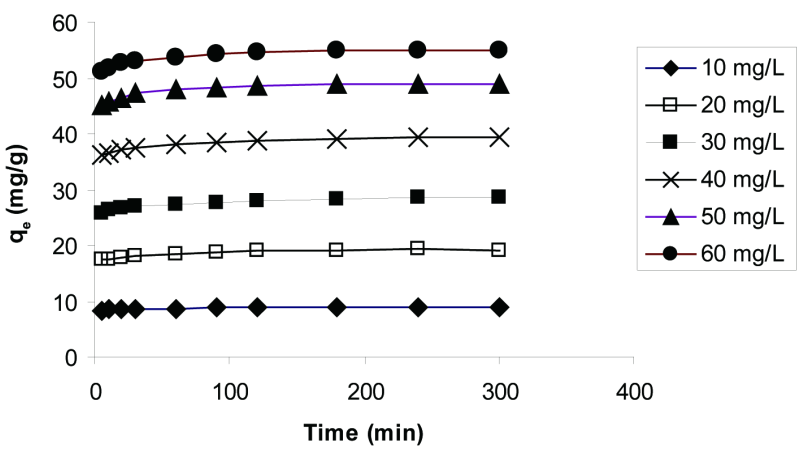

Figure 9. The effect of contact time on ethoprophos removal by $\mathrm{CH}$ (biosorbent dose, $0.1 \mathrm{~g} / 100 \mathrm{ml}$, temperature: $25^{\circ} \mathrm{C} \pm$ $\left.\mathbf{2}^{\circ} \mathrm{C}\right)$.

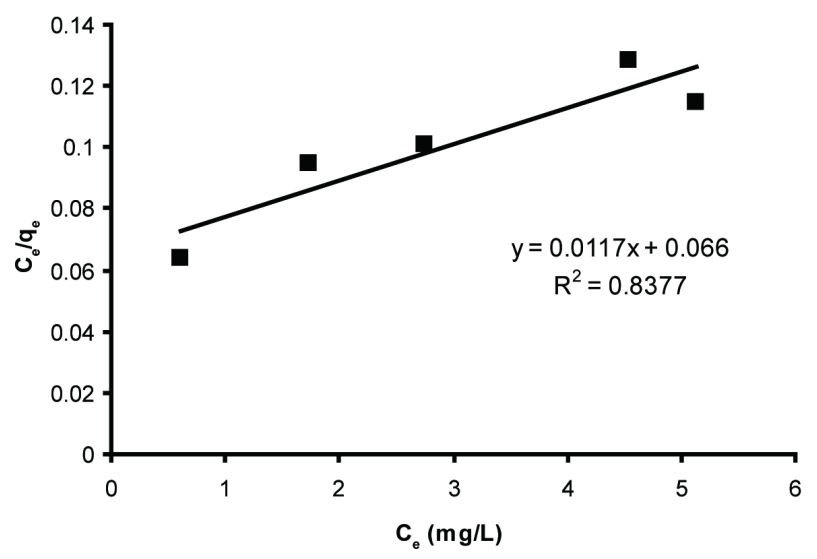

Figure 10. Langmuir adsorption isotherm for ethoprophos onto $\mathrm{CH}$.

the adsorption obeys the Langmuir model. The Langmuir constants $q_{m}$ and $b$ were determined from the slope and intercept of the plot and are presented in Table 2. One of the essential characteristics of the Langmuir isotherm can be expressed in terms of a dimensionless constant separation factor $R_{L}$ that is given by Equation (7) [61]:

$$
R_{L}=\frac{1}{1+K_{L} C_{0}}
$$

Where $C_{0}$ is the highest initial concentration of adsorbate $(\mathrm{mg} / \mathrm{L})$, and $K_{L}(\mathrm{~L} / \mathrm{mg})$ is Langmuir constant. The $R_{L}$ values between 0 and 1 indicate favorable adsorption. Table 3, shows the value of $R_{L}$ in the present investigation was found to be 0.014 indicating that the adsorption of ethoprophos on $\mathrm{CH}$ is favorable.

\subsubsection{The Freundlich Isotherm}

The Freundlich isotherm, on the other hand, assumes a heterogeneous sorption surface with sites that have different energies of sorption. The Freundlich model can be represented as:

$$
q_{e}=K_{F} C_{e}^{\frac{1}{n}}
$$


Table 2. Langmuir, Freundlich, Temkin and Dubinin-Radushkevich (D-R) isotherm models constants and correlation coefficients for adsorption of ethoprophos on Chitosan.

\begin{tabular}{cc}
\hline Isotherm model & Parameters \\
\hline Langmuir isotherm & \\
$q_{m}(\mathrm{mg} / \mathrm{g})$ & 05.47 \\
$K_{L}(\mathrm{~L} / \mathrm{mg})$ & 0.177 \\
$\mathrm{R}^{2}$ & 0.8377 \\
$R_{L}$ & 0.014 \\
Freundlich isotherm & \\
$K_{F}$ & 13.037 \\
$1 / n$ & 0.7527 \\
$\mathrm{R}^{2}$ & 0.9708 \\
Temkin isotherm & \\
$\mathrm{A}(\mathrm{L} / \mathrm{g})$ & 2.526 \\
$\mathrm{~B}$ & 15.294 \\
$\mathrm{R}^{2}$ & 0.9112 \\
$\mathrm{D}-\mathrm{R}$ isotherm & \\
$q_{m}(\mathrm{mg} / \mathrm{g})$ & 121.75 \\
$\beta\left(\mathrm{mol} / \mathrm{J}^{2}\right)$ & $1.616 \times 10^{-8}$ \\
$E(\mathrm{KJ} / \mathrm{mol})$ & 5.562 \\
$\mathrm{R}^{2}$ & 0.9316 \\
\hline
\end{tabular}

Table 3. The parameter $\boldsymbol{R}_{L}$ indicated the shape of isotherm.

\begin{tabular}{cc}
\hline Value of $R_{L}$ & Type of isotherm \\
\hline$R_{L}>1$ & Unfavorable \\
$R_{L}=1$ & Linear \\
$0<R_{L}<1$ & Favorable \\
$R_{L}=0$ & Irreversible \\
\hline
\end{tabular}

Equation (9) can be linearized in the logarithmic form (Equation (10)) and the Freundlich constants can be determined:

$$
\log q_{e}=\log K_{f}+1 / n \log C_{e}
$$

Where $K_{f}$ is the relative adsorption capacity of adsorbent and $n_{f}$ is a constant related to adsorption intensity. The plot of $\log q_{e}$ versus $\log C_{e}$ should give a straight line with a slope of $1 / n_{f}$ and intercept of $\ln K_{f}$ Figure 11. The $1 / \mathrm{n}$ is lower than 1.0 , indicating that ethoprophos is favorably adsorbed by $\mathrm{CH}$ [62]. The higher correlation coefficients $\left(\mathrm{R}^{2}\right)$ of the Freundlich isotherm suggest that Freundlich isotherm can be used to fit the experimental adsorption data for the removal of ethoprophos by Chitosan.

\subsubsection{The Temkin Isotherm}

Temkin adsorption isotherm model was used to evaluate the adsorption potentials of the ethoprophos on $\mathrm{CH}$. The derivation of the Temkin isotherm assumes that the fall in the heat of sorption is linear rather than logarithmic, as implied in the Freundlich equation. The Temkin isotherm

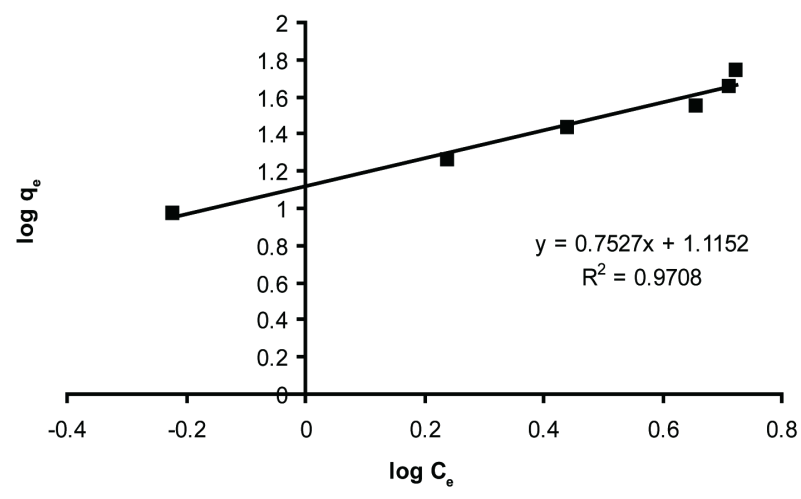

Figure 11. Freundlich adsorption isotherm for ethoprophos onto $\mathrm{CH}$

has commonly been applied in the following form [6365];

$$
q_{e}=\frac{R T}{b} \ln \left(A C_{e}\right)
$$

The Temkin isotherm, Equation (11) can be simplified to the following equation:

$$
q_{e}=\beta \ln \alpha+\beta \ln C_{e}
$$

Where $\beta=(R T) / b, T$ is the absolute temperature in Kelvin and $R$ is the universal gas constant, $8.314 \mathrm{~J}$ $(\mathrm{mol} / \mathrm{K})$. The constant $\mathrm{b}$ is related to the heat of adsorption $q_{e}(\mathrm{mg} / \mathrm{g})$ and $C_{e}(\mathrm{mg} / \mathrm{L})$ are the amount adsorbed at equilibrium and the equilibrium concentration, respectively. A and B are constants related to adsorption capacity and intensity of adsorption. Plots of $\ln C_{e}$ against $q_{e}$ for the adsorption of ethoprophos onto $\mathrm{CH}$ are given in Figure 12. The constants A and B are listed in Table 3. Examination of the data shows that the Temkin isotherm is not applicable to ethoprophos adsorption onto $\mathrm{CH}$ judged by low correlation coefficient $\mathrm{R}^{2}=0.9112$.

\subsubsection{The Dubinin-Radushkevich (D-R) Isotherm}

D-R model was applied to estimate the porosity apparent free energy and the characteristic of adsorption [66]. The $\mathrm{D}-\mathrm{R}$ isotherm is dose not assumes a homogeneous surface or constant sorption potential and it has commonly been applied in the following form (Equation (12)) and its linear form can be shown in Equation (13):

$$
\begin{gathered}
q_{e}=q_{m} \exp \left(-K \varepsilon^{2}\right) \\
\ln q_{e}=\ln q_{m}-\beta \varepsilon^{2}
\end{gathered}
$$

Where $K$ is a constant related to the adsorption energy, $q_{e}(\mathrm{mg} / \mathrm{g})$ is the amount of pesticide adsorbed per $g$ of adsorbent and $q_{m}$ represents the maximum adsorption capacity of adsorbent, $\beta\left(\mathrm{mol}^{2} / \mathrm{J}^{2}\right)$ is a constant related to adsorption energy, while $\varepsilon$ is the Polanyi potential can be calculated from Equation (14): 


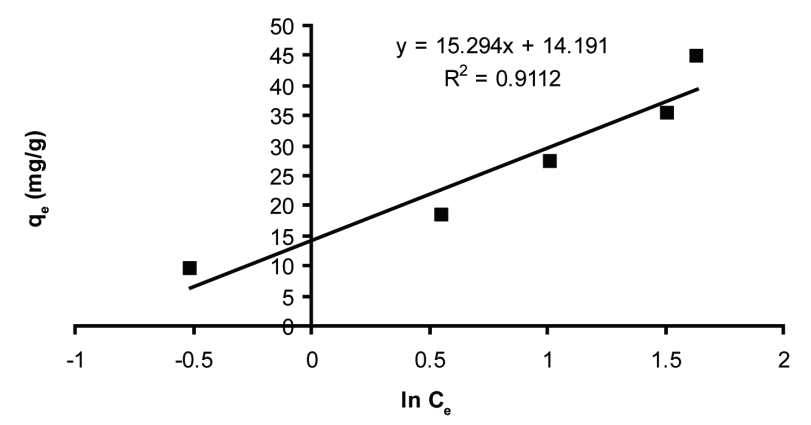

Figure 12. Temkin adsorption isotherm for ethoprophos adsorption on $\mathbf{C H}$.

$$
\varepsilon=R T \ln \left[1+\frac{1}{C_{e}}\right]
$$

The values of $\beta$ and $q_{m}$ can be obtained by plotting $\ln$ $q_{e}$ vs. $\varepsilon^{2}$. The mean free energy of adsorption $(E, \mathrm{~J} / \mathrm{mol})$, defined as the free energy change when one mole of ion is transferred from infinity in solution to the surface of the sorbent, was calculated from the $K$ value using the following relation (Equation (15)) [67]:

$$
E=1 / \sqrt{2 \beta}
$$

The calculated value of D-R parameters is given in Figure 13 and Table 2. The saturation adsorption capacity $q_{m}$ obtained using D-R isotherm model for adsorption of ethoprophos onto $\mathrm{CH}$ is $121.75 \mathrm{mg} / \mathrm{g}$. The $E$ value is useful as can be used to estimate the type of adsorption process. If the value falls in between 8 and $16 \mathrm{~kJ} / \mathrm{mol}$, the adsorption process can be explained by ion-exchange mechanism. Meanwhile, if the value is less than $8 \mathrm{~kJ} / \mathrm{mol}$, it shows that the adsorption process is of a physical nature [68]. The values of $E$ calculated using Equation (16) is $5.56 \mathrm{~kJ} / \mathrm{mol}$, which indicating that the physico-sorption process plays the significant role in the adsorption of ethoprophos onto Chitosan. To study the applicability of the Langmuir, Freundlich, Temkin and D-R isotherm models for the ethoprophos biosorption by $\mathrm{CH}$, all calculated parameters of these models are shown in Table 2. From the linear regression correlation coefficient $\mathrm{R}^{2}$, it shows that the equilibrium data could be well interpreted by the Freundlich isotherm.

\subsection{Adsorption Kinetics}

The kinetic studies provide useful data regarding the efficiency of adsorption process and feasibility of scale-up operations [69]. Several kinetic models are available to describe the adsorption kinetics. Mostly used models including the pseudo-first order, pseudo-second order and intraparticle diffusion were applied to the experimental data to evaluate the kinetics of ethoprophos adsorption by Chitosan.

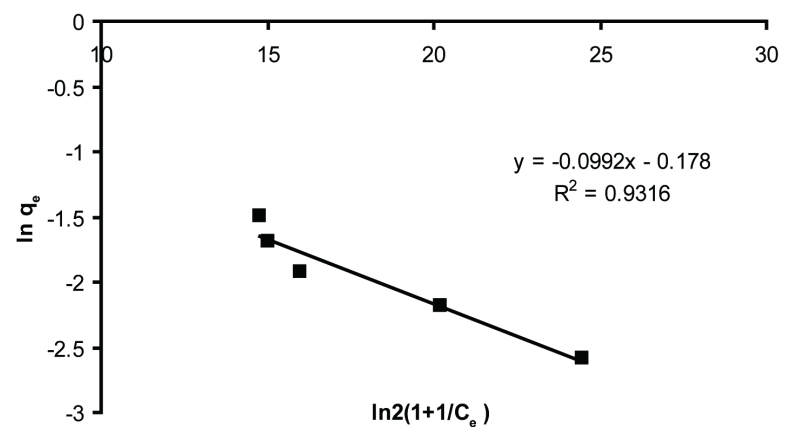

Figure 13. Dubbinin radushkevich for ethoprophos adsorption on CH.

\subsubsection{The Pseudo First-Order}

The pseudo-first order kinetic model can be expressed in a linear form as:

$$
\log \left(q_{e}-q_{t}\right)=\log \left(q_{e}\right)-\frac{K_{1}}{2.303}(t)
$$

Where $q_{e}$ and $q_{t}$ are the amount of ethoprophos adsorbed $(\mathrm{mg} / \mathrm{g})$ on the adsorbent at the equilibrium and at time $t$, respectively, and $k_{1}$ is the rate constant of adsorption $\left(\mathrm{min}^{-1}\right)$. Values of $k_{1}$ were calculated from the plots of $\log \left(q_{e}-q_{t}\right)$ versus $t$. The application of this equation to the data of ethoprophos on $\mathrm{CH}$ (data not shown) indicated the inapplicability of the model.

\subsubsection{The Pseudo-Second Order}

The Pseudo-second order kinetic model can be represented as:

$$
\frac{t}{q_{t}}=\frac{1}{K_{2} q_{e}^{2}}+\frac{1}{q_{e}}(t)
$$

Where $K_{2}$ is the rate constant for the pseudo-second order kinetics (g/mg min). The linear plot of $\left(t / q_{t}\right)$ versus $t$ is shown in Figure 14. The initial sorption rate can be calculated using the relation [70].

$$
K_{0}=K_{2} q_{e}^{2}
$$

The parameters calculated for the pseudo-second order kinetic model are listed in Table 4. As seen from the table, due to high $\mathrm{R}^{2}$, the pseudo-second order is predominant kinetic model for the ethoprophos adsorption by chitosan. Similar kinetic result was reported for hazelnut shell and Pyracantha coccinea [71,72].

\subsubsection{The Intraparticle Diffusion Model}

In order to identify the diffusion mechanism, the intraparticle diffusion model can be represented as:

$$
q_{t}=k_{i} t^{1 / 2}+C
$$

Where $K_{i}$ is the intraparticle diffusion rate constant and $C$ is a constant which gives information about the thickness of boundary layer. The intraparticle diffusion 


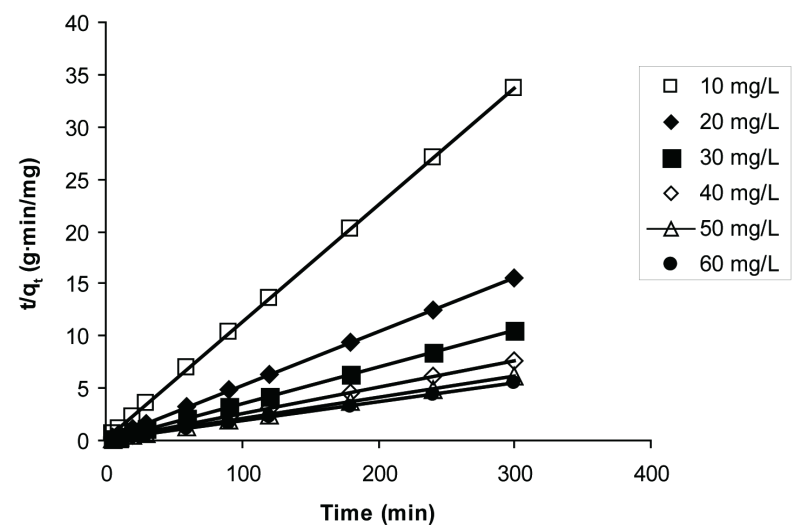

Figure 14. Pseudo-second order kinetic for adsorption of ethoprophos onto $\mathrm{CH}$.

Table 4. Kinetic models parameters adsorption of ethoprophos onto prepared chitosan at $25^{\circ} \mathrm{C}$.

\begin{tabular}{ccccccc}
\hline \multirow{2}{*}{ Parameters } & \multicolumn{6}{c}{$C_{0}(\mathrm{mg} / \mathrm{L})$} \\
\cline { 2 - 7 } & 10 & 20 & 30 & 40 & 50 & 60 \\
\hline $\begin{array}{c}\text { Pseudo-second } \\
\text { order }\end{array}$ & & & & & & \\
$K_{2}(\mathrm{~g} / \mathrm{mg} \cdot \mathrm{min})$ & 0.105 & 0.029 & 0.018 & 0.018 & 0.017 & 0.020 \\
$q_{e}(\mathrm{mg} / \mathrm{g})$ & 8.920 & 19.607 & 28.735 & 39.370 & 49.019 & 54.945 \\
$\mathrm{R}^{2}$ & 1.0000 & 0.9999 & 0.9999 & 1.0000 & 1.0000 & 1.0000 \\
$K_{0}$ & 8.354 & 11.148 & 14.862 & 28.364 & 40.848 & 60.379 \\
Intraparticle & & & & & & \\
diffusion & & & & & & \\
$K_{i}\left(\mathrm{mg} / \mathrm{g} \cdot \mathrm{min}^{1 / 2}\right)$ & 0.0618 & 0.2235 & 0.2976 & 0.336 & 0.4834 & 0.4484 \\
$\mathrm{R}^{2}$ & 0.8405 & 0.9938 & 0.9017 & 0.9706 & 0.9637 & 0.9487 \\
\hline
\end{tabular}

rate constants values are shown in Table 4 . The plot of $q_{e}$ versus $t^{1 / 2}$ Figure 15, could yield a straight line passing through the origin if the biosorption process obeys the intraparticle diffusion model. The line does not pass through the origin; therefore, intraparticle diffusion is not the only rate-limiting step. It could be stated that this process is complex and involves more than one mechanism [73]. The results demonstrated that the value of coefficient of determination $\left(\mathrm{R}^{2}\right)$ for the intraparticle diffusion was slightly lower than those of a pseudo-second order kinetic model indicating that pseudo-second order model is better obeyed than intraparticle diffusion model.

\section{Conclusion}

In this study, the biosorption removal of ethoprophos from aqueous solution by Chitosan as a low-cost and natural available adsorbent was investigated. The results show that the increase in mass biosorbent leads to increase in pesticide biosorption due to increase in number of biosorption sites. The equilibrium uptake was increased with increasing the initial concentration of pesticide in solution. The equilibrium data could be well interpreted by Freundlich isotherm. The value of activation energy

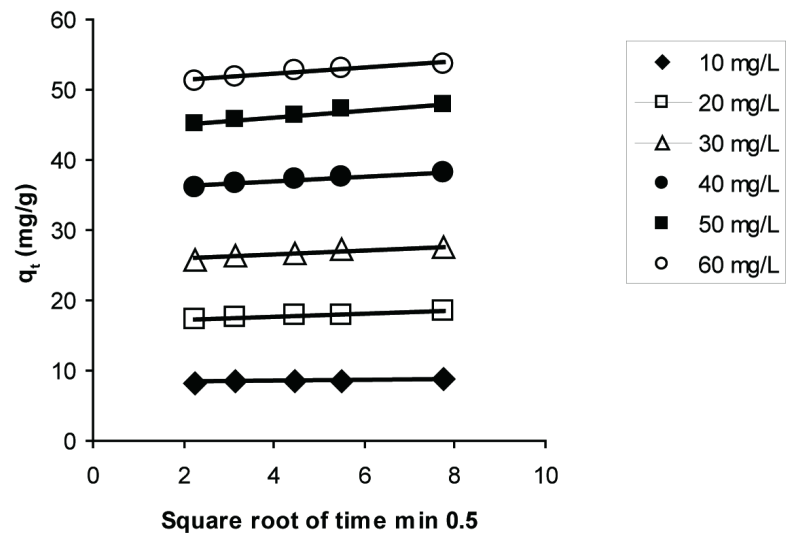

Figure 15. Intraparticle diffusion kinetic for adsorption of ethoprophos onto $\mathrm{CH}$.

calculated from the D-R isotherm model $5.56 \mathrm{KJ} / \mathrm{mol}$ suggest that the ethoprophos adsorption on $\mathrm{CH}$ is physical. Different kinetic models were used to fit experimental data. The biosorption process could be best fitted by the pseudo-second order kinetic model. The results revealed that prepared chitosan can be used as an effective natural economical biosorbent for the treatment of water containing synthetic pesticide.

\section{REFERENCES}

[1] Environment Agency, "The Annual Report of the Environment Agency Pesticide Monitoring Programme, Environment Agency,” 2002.

[2] G. Akcay, M. Akcay and K. Yurdakoc, "Removal of 2,4Dichlorophenoxyacetic Acid from Aqueous Solutions by Partially Characterized Organophilic Sepiolite: Thermodynamic and Kinetic Calculations,” Journal of Colloid and Interface Science, Vol. 281, 2005, pp. 27-32. http://dx.doi.org/10.1016/j.jcis.2004.08.080

[3] R. A. Rebich, R. H. Coupe and E. M. Thurman, "Herbicide Concentrations in the Mississippi River Basin-The Importance of Chloroacetanilide Herbicide Degradates," Science of the Total Environment, Vol. 321, 2004, pp. 189-199.

http://dx.doi.org/10.1016/j.scitotenv.2003.09.006

[4] International Agency for Research on Cancer (IARC), "Overall Evaluations of Carcinogenicity: An Updating of IARC Monographs,” Vol. 1-42, No. S7, WHO, Lyon, 1987.

[5] A. Derylo-Marczewska, M. Blachnio, A. W. Marczewski, A. Swiatkowski and B. Tarasiuk, "Adsorption of Selected Herbicides from Aqueous Solutions on Activated Carbon,” Journal of Thermal Analysis and Calorimetry, Vol. 101, 2010, pp. 785-794. http://dx.doi.org/10.1007/s10973-010-0840-7

[6] H. H. Philip, E. M. Michalenko, W. F. Jarvis, D. K. Basu, G. W. Sage, W. M. Meyland, J. A. Beauman and D. A. Gray, "Handbook of Environmental Fate and Exposure Data for Organic Chemicals,” Vol. III, Lewis, Chelsea, 1991. 
[7] M. Uğurlu and M. H. Karaoğlu, “ $\mathrm{TiO}_{2}$ Supported on Sepiolite: Preparation, Structural and Thermal Characterization and Catalytic Behaviour in Photocatalytic Treatment of Phenol and Lignin from Olive Mill Wastewater," Chemical Engineering Journal, Vol. 166, 2011, pp. 859867. http://dx.doi.org/10.1016/j.cej.2010.11.056

[8] J. Gong, C. Yang, W. Pu and J. Zhang, "Liquid Phase Deposition of Tungsten Doped $\mathrm{TiO}_{2}$ Films for Visible Light Photoelectrocatalytic Degradation of Dodecyl Benzenesulfonate," Chemical Engineering Journal, Vol. 167, 2011, pp. 190-197. http://dx.doi.org/10.1016/j.cej.2010.12.020

[9] H. Katsumata, T. Kobayashi, S. Kaneco, T. Suzuki and K. Ohta, "Degradation of Linuron by Ultrasound Combined with Photo-Fenton Treatment," Chemical Engineering Journal, Vol. 166, 2011, pp. 468-473. http://dx.doi.org/10.1016/j.cej.2010.10.073

[10] T. Zhou, T.-T. Lim, S.-S. Chin and A. G. Fane, "Treatment of Organics in Reverse Osmosis Concentrate from a Municipal Wastewater Reclamation Plant: Feasibility Test of Dvanaced Oxidation Processes with/without Pretreatment,” Chemical Engineering Journal, Vol. 166, 2011, pp. 932-939. http://dx.doi.org/10.1016/j.cej.2010.11.078

[11] H. M. Rajashekara Murthy and H. K. Manonmani, “Aerobic Degradation of Technical Hexachlorocyclohexane by a Defined Microbial Consortium," Journal of Hazardous Materials, Vol. 149, 2007, pp. 18-25.

http://dx.doi.org/10.1016/j.jhazmat.2007.03.053

[12] L. J. Banasiak, B. Van der Bruggen and A. I. Schäfer, "Sorption of Pesticide Endosulfan by Electrodialysis Membranes,” Chemical Engineering Journal, Vol. 166, 2011, pp. 233-239.

http://dx.doi.org/10.1016/j.cej.2010.10.066

[13] M. I. Maldonado, S. Malato, L. A. Perez-Estrada, W. Gernjak, I. Oller, X. Domenech and J. Peral, "Partial Degradation of Five Pesticides and an Industrial Pollutant by Ozonation in a Pilot-Plant Scale Reactor," Journal of Hazardous Materials, Vol. 38, 2006, pp. 363-369. http://dx.doi.org/10.1016/j.jhazmat.2006.05.058

[14] A. H. Al-Muhtase, K. A. Ibrahim, A. B. Albadarin, O. Alikhashman, G. M. Walker and M. N. M. Ahmad, "Remediation of Phenol-Contaminated Water by Adsorption Using Poly (Methyl Methacrylate) (PMMA)," Chemical Engineering Journal, Vol. 168, 2011, pp. 691-699. http://dx.doi.org/10.1016/j.cej.2011.01.057

[15] C. Namasivayam, R. Radhika and S. Suba, "Uptake of Dyes by a Promising Locally Available Agricultural Solid Waste: Coir Pith,” Waste Manage, Vol. 21, No. 381, 2001, p. 7.

[16] X. Y. Yang and B. Al-Duri, “Application of Branched Pore Diffusion Model in the Adsorption of Reactive Dyes on Activated Carbon," Chemical Engineering Journal, Vol. 83, 2001, pp. 15-23. http://dx.doi.org/10.1016/S1385-8947(00)00233-3

[17] G. McKay, "The Adsorption of Dyestuffs from Aqueous Solution Using Activated Carbon: Analytical Solution for Batch Adsorption Based on External Mass Transfer and Pore Diffusion,” Chemical Engineering Journal, Vol. 27, 1983, pp. 187-196. http://dx.doi.org/10.1016/0300-9467(83)80075-6

[18] I. Uzun and F. Guzel, “Adsorption of Some Heavy Metal Ions from Aqueous Solution by Activated Carbon and Comparison of Percent Adsorption Results of Activated Carbon with Those of Some Other Adsorbents,” Turkish Journal of Chemistry, Vol. 24, 2000, pp. 291-297.

[19] S. J. Allen and G. McKay, "Diffusion Model for the Sorption of Dyes on Peat," Journal of Separating and Processing Technology, Vol. 8, 1987, pp. 18-25.

[20] G. McKay, H. S. Blair and J. Gardner, "Rate Studies for the Adsorption of Dyestuffs onto Chitin," Journal of Colloid and Interface Science, Vol. 95, 1983, pp. 108-119. http://dx.doi.org/10.1016/0021-9797(83)90078-4

[21] G. McKay, M. S. Otterburn and A. G. Sweeney, "Surface Mass Transfer Processes during Colour Removal from Effluent Using Silica,” Water Research, Vol. 15, 1991, pp. 327-331. http://dx.doi.org/10.1016/0043-1354(81)90036-1

[22] G. S. Gupta, G. Prasad and V. N. Singh, "Removal of Chrome Dye from Aqueous Solutions by Mixed Adsorbents: Fly Ash and Coal,” Water Research, Vol. 24, 1990, pp. 45-50. http://dx.doi.org/10.1016/0043-1354(90)90063-C

[23] V. V. Sethuraman and B. C. Raymahashay, "Color Removal by Clays. Kinetic Study of Adsorption of Cationic and Anionic Dyes," Environmental Science \& Technology, Vol. 9, No. 11, 1975, pp. 39-40.

[24] R. W. Frei and H. Zeitlin, "The Factors Affecting the Reflectance Spectra of Some Dyes Adsorbed on Alumina," Analytica Chimica Acta, Vol. 32, 1965, pp. 32-39. http://dx.doi.org/10.1016/S0003-2670(00)88888-1

[25] D. Roy, P. N. Greenlaw and B. S. Shane, "Adsorption of Heavy Metals by Green Algae and Ground Rice Hulls,” Journal of Environmental Science and Health, Vol. A28, 1993, pp. 37-50.

[26] F. Shahidi and R. Abuzaytoun, "Chitin, Chitosan, and CoProducts: Chemistry, Production, Applications, and Health Effects," Advances in Food and Nutrition Research, Vol. 49, 2005, pp. 93-135. http://dx.doi.org/10.1016/S1043-4526(05)49003-8

[27] R. N. Tharanathan and F. S. Kittur, "Chitin-The Undisputed Biomolecule of Great Potential," Critical Reviews in Food Science and Nutrition, Vol. 43, 2003, pp. 61-87. http://dx.doi.org/10.1080/10408690390826455

[28] I. Uzun and F. Guzel, "Kinetics and Thermodynamics of the Adsorption of Some Dyestuffs and P-Nitrophenol by Chitosan and MCMchitosan from Aqueous Solution," Journal of Colloid and Interface Science, Vol. 274, 2004, pp. 398-412. http://dx.doi.org/10.1016/j.jcis.2004.02.022

[29] I. Uzun and F. Guzel, “Adsorption of Some Heavy Metal Ions from Aqueous Solution by Activated Carbon and Comparison of Percent Adsorption Results of Activated Carbon with Those of Some Other Adsorbents," Turkish Journal of Chemistry, Vol. 24, 2000, pp. 291-297.

[30] X. F. Zeng and E. Ruckenstein, “Cross-Linked Macroporous Chitosan Anion-Exchange Membranes for Protein Separathions,” Journal of Membrane Science, Vol. 148, 1998, pp. 195-205. 
http://dx.doi.org/10.1016/S0376-7388(98)00183-5

[31] MNVR Kumar, "A Review of Chitin and Chitosan Applications," Reactive and Functional Polymers, Vol. 46, 2000, pp. 1-27.

http://dx.doi.org/10.1016/S1381-5148(00)00038-9

[32] E. Agullo, M. S. Rodriguez, V. Ramos and L. Albertengo, "Present and Future Role of Chitin and Chitosan in Food," Macromolecular Bioscience, Vol. 3, 2003, pp. 521-530. http://dx.doi.org/10.1002/mabi.200300010

[33] F. Shahidi, J. K. V. Arachchi and Y. J. Jeon, "Food Applications of Chitin and Chitosans," Trends in Food Science \& Technology, Vol.10, 1999, pp. 37-51. http://dx.doi.org/10.1016/S0924-2244(99)00017-5

[34] M. Prabaharan and J. F. Mano, "Chitosan-Based Particles as Controlled Drug Delivery Systems,” Drug Delivery, Vol. 12, 2005, pp. 41-57.

http://dx.doi.org/10.1080/10717540590889781

[35] M. N. V. Ravi Kumar, R. A. A. Muzzarelli, C. Muzzarelli, H. Sashiwa and A. J. Domb, "Chitosan Chemistry and Pharmaceutical Perspectives,” Chemical Reviews, Vol. 104, 2004, pp. 6017-6084. http://dx.doi.org/10.1021/cr030441b

[36] S. A. Agnihotri, N. N. Mallikarjuna and T. M. Aminabhavi, "Recent Advances on Chitosan-Based Micro- and Nanoparticles in Drug Delivery," Journal of Controlled Release, Vol. 100, No. 1, 2004, pp. 5-28. http://dx.doi.org/10.1016/j.jconrel.2004.08.010

[37] S. Senel and S. J. McClure, "Potential Applications of Chitosan in Veterinary Medicine," Advanced Drug Delivery Reviews, Vol. 56, No. 10, 2004, pp. 1467-1480. http://dx.doi.org/10.1016/j.addr.2004.02.007

[38] J. Berger, M. Reist, J. M. Mayer, O. Felt, N. A. Peppas and R. Gurny, "Structure and Interactions in Covalently and Ionically Crosslinked Chitosan Hydrogels for Biomedical Applications," European Journal of Pharmaceutics and Biopharmaceutics, Vol. 57, No. 1, 2004, pp. 19-34. http://dx.doi.org/10.1016/S0939-6411(03)00161-9

[39] E. Khor and L.Y. Lim, "Implantable Applications of Chitin and Chitosan,” Biomaterials, Vol. 24, No. 13, 2003, pp. 2339-2349. http://dx.doi.org/10.1016/S0142-9612(03)00026-7

[40] M. N. V. Ravi Kumar, "A Review of Chitin and Chitosan Applications,” Reactive and Functional Polymers, Vol. 46, No. 1, 2000, pp. 1-27. http://dx.doi.org/10.1016/S1381-5148(00)00038-9

[41] B. Krajewska, "Applications of Chitin- and ChitosanBased Materials for Enzyme Immobilizations,” Enzyme and Microbial Technology, Vol. 35, No. 2-3, 2004, pp. 126139. http://dx.doi.org/10.1016/j.enzmictec.2003.12.013

[42] S. Bautista-Banos, A. N. Hernandez-Lauzardo, M. G. Velazquez-del Valle, M. Hernandez-Lopez, E. Ait Barka, E. Bosquez-Molina and C. L. Wilson, "Chitosan as a Potential Natural Compound to Control Pre and Post Harvest Diseases of Horticultural Commodities," Crop Protection, Vol. 25, No. 2, 2006, pp. 108-118. http://dx.doi.org/10.1016/j.cropro.2005.03.010

[43] C. D. S. Tomlin, “The e-Pesticides Manual,” Version 3.0, 13th ed., BCPC (British Crop Protection Council), Copy- right (C) (2004).

[44] Z. Abdeen, "Preparations and Applications of Some Friendly Environmental Compounds,” Ph.D. Thesis, AinShams University, Cairo, 2005.

[45] M. Mima, S. Mima, M. Miya, R. Iwamoto and S. Yoshikawa, "Highly Deacetylated Chitosan and Its Properties," Journal of Applied Polymer Science, Vol. 28, No. 6, 1983, pp. 1909-1917. http://dx.doi.org/10.1002/app.1983.070280607

[46] R. Ferrus and P. Pages, "Water Retention Value and Degree of Crystallinity by Infrared Absorption Spectroscopy in Caustic-Soda-Treated Cotton," Cellulose Chemistry and Technology, Vol. 11, No. 6, 1977, pp. 633-637.

[47] G. McKay, H. S. Blair and J. R. Gardner, "Two Resistance Mass Transport Model for the Adsorption of Acid Dye Onto Chitin in Fixed Beds," Journal of Applied Polymer Science, Vol. 33, No. 4, 1987, pp. 1247-1256.

[48] F. N. Arslanoglu, F. Kar and N. Arslan, “Adsorption of Dark Coloured Compounds from Peach Pulp by Using Powdered Activated Carbon,” Journal of Food Engineering, Vol. 71, No. 2, 2005, pp. 156-163. http://dx.doi.org/10.1016/j.jfoodeng.2004.10.029

[49] H. B. Senturk, D. Ozdes and C. Duran, "Biosorption of Rhodamine 6G from Aqueous Solutions onto Almond shell (Prunus dulcis) as a Low Cost Biosorbent,” Desalination, Vol. 252, No. 1-3, 2010, pp. 81-87. http://dx.doi.org/10.1016/j.desal.2009.10.021

[50] P. S. Kumar, S. Ramalingam, C. Senthamarai, M. Niranjanaa, P. Vijayalakshmi and S. Sivanesan, “Adsorption of Dye from Aqueous Solution by cashew Nut Shell: Studies on Equilibrium Isotherm, Kinetics and Thermodynamics of Interactions,” Desalination, Vol. 261, No. 1-2, 2010, pp. 52-60. http://dx.doi.org/10.1016/j.desal.2010.05.032

[51] S. D. Khattri and M. K. Singh, "Removal of Malachite Green from Dye Wastewater Using Neem Sawdust by Adsorption,” Journal of Hazardous Materials, Vol. 167, No. 1-3, 2009, pp. 1089-1094. http://dx.doi.org/10.1016/j.jhazmat.2009.01.101

[52] R. Ahmed, "Studies on Adsorption of Crystal Violet Dye from Aqueous Solution onto Coniferous Pinus Bark Powder (CPBP)," Journal of Hazardous Materials, Vol. 171, No. 1-3, 2009, pp. 767-773. http://dx.doi.org/10.1016/j.jhazmat.2009.06.060

[53] N. Nasuha, B. H. Hameed and A. T. M. Din, "Rejected Tea as a Potential Low-Cost Adsorbent for the Removal of Methylene Blue,” Journal of Hazardous Materials, Vol. 175, No. 1-3, 2010, pp. 126-132. http://dx.doi.org/10.1016/j.jhazmat.2009.09.138

[54] M. Dogan, H. Abak and M. Alkan, “Adsorption of Methylene Blue onto Hazelnut Shell: Kinetics, Mechanism and Activation Parameters," Journal of Hazardous Materials, Vol. 164, No. 1, 2009, pp. 172-181. http://dx.doi.org/10.1016/j.jhazmat.2008.07.155

[55] N. M. Mahmoodi, R. Salehi and M. Arami, "Binary System Dye Removal from Colored Textile Wastewater Using Activated Carbon: Kinetic and Isotherm Studies,” Desalination, Vol. 272, No. 1-3, 2011, pp. 187-195. http://dx.doi.org/10.1016/j.desal.2011.01.023 
[56] I. Langmuir, "The Adsorption of Gases on Plane Surfaces of Glass, Mica and Platinum," Journal of the American Chemical Society, Vol. 40, No. 9, 1918, pp. 1361-1403. http://dx.doi.org/10.1021/ja02242a004

[57] H. Freundlich, "Over the Adsorption in the Solution,” Journal of Physical Chemistry, Vol. 57, No. 4, 1906, pp. 385470.

[58] M. M. Dubinin and L. V. Radushkevich, "Equation of the Characteristic Curve of Activated Charcoal," Proceedings of the Academy of Sciences USSR, Vol. 55, No. 2, 1947, pp. 331-333.

[59] M. J. Temkin and V. Pyzhev, "Kinetics of Ammonia Synthesis on Promoted Iron Catalysts," Acta Physicochim. URSS, Vol. 12, No. 1, 1940, pp. 217-222.

[60] I. Langmuir, "The Constitution and Fundamental Properties of Solids and Liquids," Journal of the American Chemical Society, Vol. 38, No. 11, 1916, pp. 2221-2295. http://dx.doi.org/10.1021/ja02268a002

[61] K.R. Hall, L.C. Eagleton, A. Acrivos and T. Vermeulen, "Pore-and Solid-Diffusion Kinetics in Fixed-Bed Adsorption under Constant-Pattern Conditions," Industrial \& Engineering Chemistry Fundamentals, Vol. 5, No. 2, 1966, pp. 212-223. http://dx.doi.org/10.1021/i160018a011

[62] H. B. Senthil Kumar, S. Ramalingam, C. Senthamarai, M. Niranjanaa, P. Vijayalakshmi and S. Sivanesan, “Adsorption of Dye from Aqueous Solution by Cashew Nut Shell: Studies of Equilibrium Isotherm, Kinetics and Thermodynamics of Interactions,” Desalination, Vol. 261, No. 1-2, 2010, pp. 52-60. http://dx.doi.org/10.1016/j.desal.2010.05.032

[63] C. Aharoni and D. L. Sparks, "Kinetics of Soil Chemical Reactions-A Theoretical Treatment,” In: D. L. Sparks and D. L. Suarez, Eds., Rate of Soil Chemical Processes, Soil Science Society of America, Madison, 1991, pp. 1-18.

[64] C. Aharoni and M. Ungarish, "Kinetics of Activated Chemisorptions, Part 2.-Theoretical Models," Journal of the Chemical Society, Faraday Transactions 1, Vol. 73, No. 2, 1977, pp. 456-464. http://dx.doi.org/10.1039/f19777300456

[65] X. S. Wang and Y. Qin, "Equilibrium Sorption Isotherms for of $\mathrm{Cu}^{2+}$ on Rice Bran,” Process Biochemistry, Vol. 40,
No. 2, 2005, pp. 677-680.

http://dx.doi.org/10.1016/j.procbio.2004.01.043

[66] M. M. Dubinin, "Modern State of the Theory of Volume Filling of Micropore Adsorbents during Adsorption of Gases and Steams on Carbon Adsorbents," Zhurnal Fizicheskoi Khimii, Vol. 39, No. 19, 1965, pp. 1305-1317.

[67] L. V. Radushkevich, "Potential Theory of Sorption and Structure of Carbons,” Zhurnal Fizicheskoi Khimii, Vol. 23, No. 12, 1949, pp. 1410-1420.

[68] N. Unlu“and M. Ersoz, "Adsorption Characteristics of Heavy Metal Ions onto a Low Cost Biopolymer Sorbent from Aqueous Solutions”. Journal of Hazardous Materials, Vol. 136, No. 2, 2006, pp. 272-280.

[69] T. Calvete, E. C. Lima, N. F. Cardoso, S. L. P. Dias and F. A. Pavan, "Application of Carbon Adsorbents Prepared from the Brazilian-Pine Fruit Shell for Removal of Procion Red MX 3B from Aqueous Solution. Kinetic, Equilibrium, and Thermodynamic Studies," Chemical Engineering Journal, Vol. 155, No. 3, 2009, pp. 627-636. http://dx.doi.org/10.1016/j.cej.2009.08.019

[70] H. Koynucu, "Adsorption Kinetics of 3-Hydroxybenzaldehyde on Native and Activated Bentonite,” Applied Clay Science, Vol. 38, No. 3-4, 2008, pp. 279-287. http://dx.doi.org/10.1016/j.clay.2007.03.010

[71] Y. Safa and H. N. Bhatti, "kinetic and Thermodynamic Modeling for the Removal of Direct Red-31 and Direct Orange-26 Dyes from Aqueous Solutions by Rice Husk," Desalination, Vol. 272, No. 1-3, 2011, pp. 313-322. http://dx.doi.org/10.1016/j.desal.2011.01.040

[72] T. Akar, S. Celik and S. T. Akar, "Biosorption Performance of Surface Modified Biomass Obtained from Pyracantha coccinea for the Decolonization of Dye Contaminated Solutions,” Chemical Engineering Journal, Vol. 160, No. 2, 2010, pp. 466-472. http://dx.doi.org/10.1016/j.cej.2010.03.047

[73] M. A. Al-Ghouti, M. N. M. Ahmed and S. Allen, “Adsorption Behaviour of Methylene Blue onto Jordanian Diatomite: A Kinetic Study,” Journal of Hazardous Materials, Vol. 165, No. 1-3, 2009, pp. 589-598. http://dx.doi.org/10.1016/j.jhazmat.2008.10.018 